\title{
Megakaryoblast Cell Count
}

National Cancer Institute

\section{Source}

National Cancer Institute. Megakaryoblast Cell Count. NCI Thesaurus. Code C98752.

The determination of the amount of megakaryoblasts present in a sample. 